\title{
The Association of Hepatitis B and C Virus Co-infections with B-Cell Non-Hodgkin Lymphoma
}

\author{
A. Barbullushi ${ }^{1}$, XH. Deda ${ }^{2}$, D. Bali Alia ${ }^{3}$, F. Prifti $^{4}$, J. Basho $^{5}$ \\ ${ }^{1}$ Clinical-biochemical Laboratory Departament, Universitary Hospital center “Mother Teresa “, Tirane, Albania \\ ${ }^{2,4,5}$ Gastro-HepatologyDepartament, Universitary Hospital center "Mother Teresa “, Tirane, Albania \\ ${ }^{3}$ Pediatric OncohematologyDepartment, Universitary Hospital center "Mother Teresa “, Tirane, Albania
}

\begin{abstract}
Non-Hodgkin lymphoma (NHL) is the hematologic malignancy with the highest prevalence worldwide. Hepatitis B virus (HBV) and hepatitis C virus (HCV) are hepatotropic viruses that can also replicate in lymphoid cells. This has led to evaluation of potential associations between HCV and HBV infection with B-cell non-Hodgkin's lymphoma (BNHL) as well as other hematologic malignancies. HCV has been the most frequently studied association between a hepatitis virus and NHL. Recent literature has associated hepatitis $C$ virus with the development of non-Hodgkin lymphoma. The association of NHL with HBV has been studied much less intensively than with $\mathrm{HCV}$. The aim of this paper was to report the case of a 43-year-old male patient, who was diagnosed and treated for chronic hepatitis $B$ and hepatitis $C$ in our service. The patient developed Non-Hodgkin B cell malign lymphoma while being on treatment with Pegylated Interferon for HCV and HBV infection.
\end{abstract}

Keywords: Non-Hodgkin lymphoma (NHL), hematologic malignancies,Hepatitis B virus, Hepatitis C virus

\section{Introduction}

Non-Hodgkin lymphoma (NHL) is the hematologic malignancy with the highest prevalence worldwide. Incidence rates have grown fast up to the beginning of the new millennium, with an annual percentage increase of nearly $3 \%$, which is faster than for most cancers (1). Hepatitis $\mathrm{B}$ virus (HBV) and hepatitis $\mathrm{C}$ virus (HCV) are hepatotropic viruses that can also replicate in lymphoid cells $(2,3)$. This has led to evaluation of potential associations between HCV and HBV infection with B-cell non-Hodgkin's lymphoma (BNHL) as well as other hematologic malignancies.

The most frequently studied association between a hepatitis virus and NHL has been with $\mathrm{HCV}$. Hepatitis $\mathrm{C}$ virus (HCV) has been recognized as a potential cause of B-cell lymphoma. The management of these lymphomas is also complicated by the presence of the underlying chronic $\mathrm{HCV}$ infection $(4,5)$. The potential association of HCV and nonHodgkin's lymphomas (NHL) was first recognized while studying patients with essential mixed cryoglobulinaemia (EMC), a chronic autoimmune disease with an underlying bone marrow B-cell clonal proliferation (6). Chronic hepatitis $\mathrm{C}$ infection was recognized as the principle cause of EMC, with antibodies to the virus found in $84-98 \%(7,8)$ of patients with EMC. EMC predisposed to development of malignant lymphoma (9), prompting further studies on the association between hepatitis $\mathrm{C}$ and lymphomas.

The association of NHL with HBV has been studied much less intensively than with $\mathrm{HCV}$. Epidemiological studies performed over the last decade have demonstrated a positive association between persistent, hepatitis B surface antigen (HBsAg)-positive hepatitis B virus (HBV) infection and Bcell non-Hodgkin lymphoma (NHL), with HBV-infected patients having a 2-3-fold higher risk to develop NHL than non-infected patients. Moreover, there is evidence that also occult HBV infection (HBsAg-negative, HBV DNApositive) associates with NHL (10). The majority of lymphomas presenting concurrently with $\mathrm{HCV}$ carriage should be managed in a similar manner to their HCVnegative counterparts. For certain low-grade lymphomas there is increasing evidence that treatment of the HCV with antiviral therapy can lead to remission of the lymphoma. The underlying B-cell monoclonal proliferation associated with EMC can be cleared when the $\mathrm{HCV}$ is treated with interferon- $\alpha($ IFN- $\alpha)(11)$ and there are case reports of longlasting complete remission of frank lymphoplasmacytoidlymphoma concurrent with eradication of the virus with IFN- $\alpha$ (12).

We represent who developed non-Hodgkin lymphoma while being on treatment with Pegylated INF for the HBV and HCV chronic infection.

\section{Case Presentation}

A 43 years old male presented to the Department of Gastroenterology and Hepathology, Mother Teresa Hospital, Albania, as an HCV and HBV positive patient from 3 months in order to be further diagnosed and treated. Pegylated Interferon and Ribavirine treatment was started to the patient. During the treatment the patient HCV RNA got negative, while the HBV DNA was constantly positive. He had a 10 year history for venous ulcer of the leg. Beside this the medical history was unremarkable.

At the 52 week of the treatment the patient complaint of abdominal pain of the right upper quadrant, fatigue, high grade fever, throat ache, head ache, weight loss and difficulty in breathing. 


\section{International Journal of Science and Research (IJSR) \\ ISSN (Online): 2319-7064}

Index Copernicus Value (2013): 6.14 | Impact Factor (2014): 5.611

On examination patient was conscious, oriented and febrile, the liver and spleen were enlarged, peripheral lymph nodules were palpable and there were mild bilateral lower extremity edema. Blood profile showed decreased hemoglobin level and severe thrombocytopenia (Table Nr.1). Leucocyte formula in microscope showed mononuclear elements with single big nucleus and basophilic cytoplasm. This image was suggestive of a typical view of a lymphoma cell (Figure nr. $1)$.

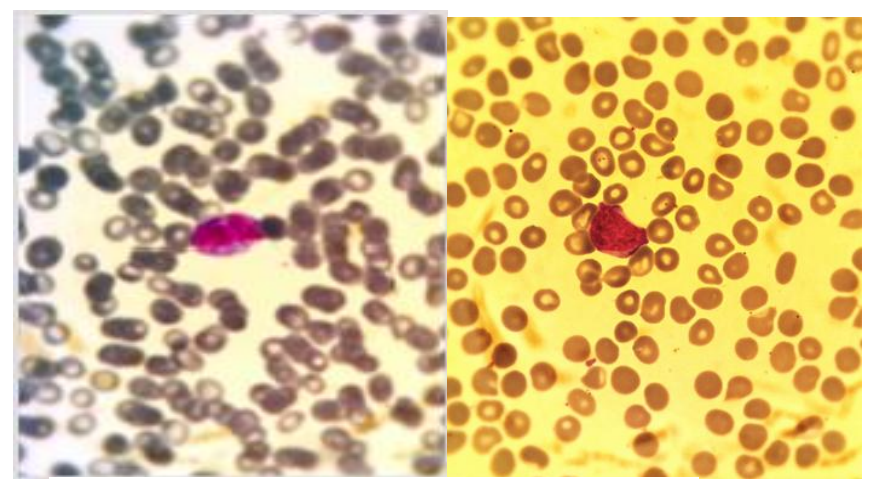

Figure 1: Periferic blood smear. Limfoma cell

Biochemistry blood test showed low value of protein, albumin and cholesterol (Table Nr. 1). Beside this the liver and renal biochemical profiles were between the ranges of normal. Serum protein electrophoresis was normal. Prothrombin time level was also normal.

Table 1

\begin{tabular}{|c|c|c|}
\hline Parameters & Value & Normal level \\
\hline RBC & $3.74^{\wedge} 10^{6}$ & $4.4-10.0^{\wedge} 10^{6}$ \\
\hline Hemoglobin & $9.8 \mathrm{~g} / \mathrm{dl}$ & $12.0-16.5$ \\
\hline PLT & $14^{\wedge} 10^{3}$ & $150-400^{\wedge} 10^{3}$ \\
\hline Total protein & $5.8 \mathrm{~g} / \mathrm{dl}$ & $6.0-8.3$ \\
\hline Albumin & $2.9 \mathrm{~g} / \mathrm{dl}$ & $3.5-5.2$ \\
\hline Cholesterol & $19 \mathrm{mg} / \mathrm{dl}$ & $140-220$ \\
\hline
\end{tabular}

The patient was tested positive for $\mathrm{HbsAg}$ and anti.HCV, while anti HDV was negative. HCV RNA was negative during the treatment while HBV DNA remained positive. HCV genotype was 3 .

The patient was further recommended for abdominal ultrasound. Enlarged liver and also periportal lymphadenopathy were seen. Also there were sign of portal hypertension with portal vein diameter $18 \mathrm{~mm}$ and much enlarged spleen. Liver elastography value was $14.8 \mathrm{kPa}$ which correlate with F4 liver stiffness. On upper endoscopy there were esophageal varices.

The immunophenotype for lymphoma was positive for CD45, CD19 and CD20 suggesting for malignant nonHodgkin's B cell lymphoma.

FNAC (fine needle aspiration cytology) of the peripheral axillar lymph nodes showed high grade malignant nonHodgkin's B cell lymphoma (Figure Nr. 2).

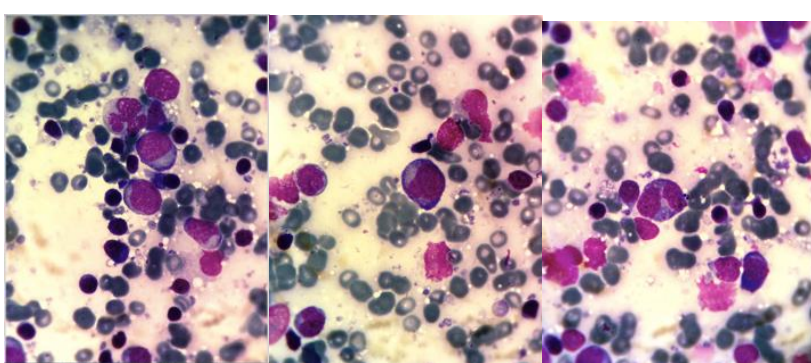

Figure 2: Fine needle aspiration of axillar limfonodul.

\section{Lymphoma cell}

Computed Tomography (CT) of the abdomen showed mediastinal, bilateral axillar, inguinal and retroperitoneal lymphadenopathy (Figure $\mathrm{nr} 3$ ), hepatosplenomegaly and no peritoneal ascites. The chest X-ray was normal. In our service the patient was treated with Dexamethasone infusion $16 \mathrm{mg}$ daily and tramadol infusion according the patient pain level. After diagnose confirmation the patient was presented to the oncologic department for further diagnose and treatment.

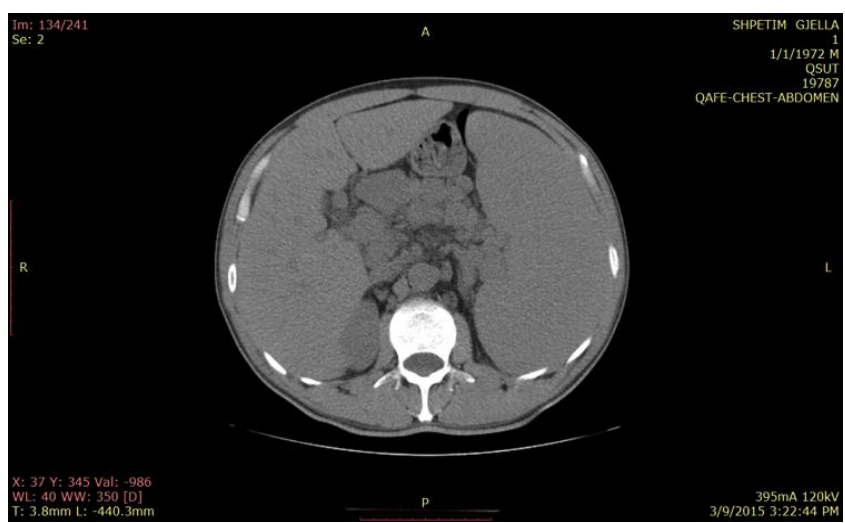

Figure 3: Aksial non-enhanced CT Images oF the upper abdomen

\section{Conclusion}

Non Hodgkin B cell lymphoma is a life threatening disease which should be diagnosed and treated adequately. The clinic presentation, laboratory analyses and radiologic images information are needed to put the right diagnose. On the other hand HBV and HCV chronic infection are known to be associated with higher risk of non-Hodgkin B cell lymphoma. The treatment of choice for HBV and HCV confection is Pegylated INF and Ribavirine treatment. This treatment is known to be associated with multiple adverse effects including head ache, fatigue, abdominal pain, throat ache, head ache, anemia and thrombocytopenia. Most of the mentioned side effects are also present in patient with nonHodgkin lymphoma. That is why we recommend checking for non-Hodgkin B cell lymphoma in HBV and HCV patients with continuously severe thrombocytopenia and rapid progression of the clinic presentation while on treatment with Pegylated INF.

\section{References}

[1] G. Gribben, "How I treat indolent lymphoma," Blood, vol. 109, no. 11, pp. 4617-4626, 2007 


\section{International Journal of Science and Research (IJSR) \\ ISSN (Online): 2319-7064}

Index Copernicus Value (2013): 6.14 | Impact Factor (2014): 5.611

[2] Yoffe B, Noonan CA, Melnick JL, Hollinger F. Hepatitis B virus DNA in mononuclear cells and analysis of cell subsets for the presence of replicative intermediates of viral DNA. J Infect Dis 1986;153:471-7

[3] Bronowicki JP, Loriot MA, Thiers V, Grignon Y, Zignego AL, Bréchot C. Hepatitis $\mathrm{C}$ virus persistence in human hematopoietic cells injected into SCID mice. Hepatology 1998;28:211-8

[4] Zuckerman E, Zuckerman T, Douer D et al. Liver dysfunction in patients infected with hepatitis $\mathrm{C}$ virus undergoing chemotherapy for hematologic malignancies. Cancer 1998; 83: 1224-1230

[5] Vento S, Cainelli F, Mirandola F et al. Fulminant hepatitis on withdrawal of chemotherapy in carriers of hepatitis C virus. Lancet1996; 347: 92-93

[6] Monteverde A, Rivano MT, Allegra GC et al. Essential mixed cryoglobulinemia, type II: a manifestation of a low-grade malignant lymphoma? Clinicalmorphological study of 12 cases with special reference to immunohistochemical findings in liver frozen sections. Acta Haematol1988; 79: 20-25

[7] Agnello V, Chung RT, Kaplan LM.A role for hepatitis C virus infection in type II cryoglobulinemia. N Engl J Med1992; 327: 1490-1495

[8] Misiani R, Bellavita P, Fenili D et al. Hepatitis C virus infection in patients with essential mixed cryoglobulinemia. Ann Intern Med1992; 117: 573-577

[9] Pozzato G, Mazzaro C, Crovatto $M$ et al. Low-grade malignant lymphoma, hepatitis $\mathrm{C}$ virus infection, and mixed cryoglobulinemia. Blood1994; 84: 3047-3053

[10] FabrizioMarcucci,1,2 Enea Spada,1 Alfonso Mele,1 Carmelo Antonio Caserta, 2 and Alessandro Pulsoni 3. The association of hepatitis B virus infection with B-cell non-Hodgkin lymphoma - a review

[11] Mazzaro C, Franzin F, Tulissi P et al. Regression of monoclonal B-cell expansion in patients affected by mixed cryoglobulinemia responsive to $\alpha$-interferon therapy. Cancer1996; 77: 2604-2613

[12] Patriarca F, Silvestri F, Fanin R et al. Long-lasting complete remission of hepatitis $\mathrm{C}$ virus (HCV) infection and $\mathrm{HCV}$-associated immunocytoma with $\alpha$-interferon treatment. Br J Haematol2001; 112: 370-372

[13] Ref. Ekström-Smedby K. Epidemiology and etiology of non-Hodgkin lymphoma-a review et al. ActaOncol. 2006; 45(3):258-71

[14]Bloomfield CD, McKenna RW, Brunning RD. Significance of haematological parameters in the nonHodgkin's malignant lymphomas. Br J Haematol 1976; $32: 41$

[15] Conlan MG, Armitage JO, Bast M, Weisenburger DD. Clinical significance of hematologic parameters in nonHodgkin's lymphoma at diagnosis. Cancer 1991; 67:1389

[16] Fried MW.Side effects of therapy of hepatitis C and their anagement. Hepatology. 2002;36:S237-S244. doi: 10.1002/hep.1840360730)

[17] Barrington SF, Mikhaeel NG, Kostakoglu L, et al. Role of imaging in the staging and response assessment of lymphoma: consensus of the International Conference on Malignant Lymphomas Imaging Working Group. J ClinOncol 2014; 32:3048

[18] Hernandez-Maraver D, Hernandez-Navarro F, GomezLeon N, et al. Positron emission tomography/computed tomography: diagnostic accuracy in lymphoma. $\mathrm{Br} J$ Haematol 2006; 135:293

[19]Zeppa P, Marino G, Troncone G, et al. Fine-needle cytology and flow cytometryimmunophenotyping and subclassification of non-Hodgkin lymphoma: a critical review of 307 cases with technical suggestions. Cancer 2004; 102:55

[20] Luoni M, Declich P, Fava S, et al. Bone marrow biopsy for the staging of non-Hodgkin's lymphoma: bilateral or unilateral trephine biopsy? Tumori 1995; 81:410

[21] Hehn ST, Grogan TM, Miller TP. Utility of fine-needle aspiration as a diagnostic technique in lymphoma. J ClinOncol 2004; 22:3046

[22] Doberneck RC.The diagnostic yield of lymph node biopsy. Arch Surg 1983; 118:1203

[23] Lee Y, Terry R, Lukes RJ. Lymph node biopsy for diagnosis: a statistical study. J SurgOncol 1980; 14:53

\section{Author Profile}

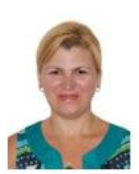

Alma Barbullushi, is graduated at the Faculty of Medicine, University Tirana, Albania. $\mathrm{PhD}$ in Laboratory Medicine. Currently, works at the Laboratory Department, University Hospital Center "Mother Theresa", Tirana, Albania

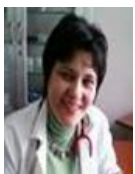

Donjeta Bali Alia, is graduated in the Faculty of Medicine, University of Tirana, Albania. PhD in the Pediatric Oncoematology. Currently, works at Pediatric Oncohematologic Service- University Hospital Center "Mother Theresa", Tirana, Albania

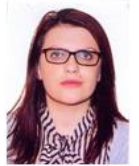

Fjoralba Prifti, is graduated in the Faculty of Medicine, University of Tirana, Albania. Currently, Specialization in GastrohepatologyService- University Hospital Center "Mother Theresa", Tirana, Albania

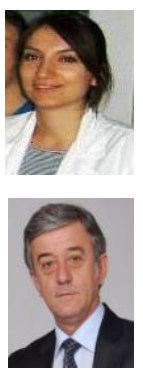

Xheni Deda, is graduated in the Faculty of Medicine, University of Tirana, Albania. Specialization in GastrohepatologyService- University Hospital Center "Mother Theresa", Tirana, Albania.

Prof. Dr. Jovan Basho, is graduated in the Faculty of the Medicine with excellent grades. He is professor at Faculty of the Medicine, University of Medicine, Tirane. Currently Prof. Dr. Jovan Bashaworks at Hepatology-Gastrohepatology service, University Hospital Center "Mother Theresa", Tirana, Albania. 